medRxiv preprint doi: https://doi.org/10.1101/2020.05.15.20084293; this version posted May 21 , 2020. The copyright holder for this preprint (which was not certified by peer review) is the author/funder, who has granted medRxiv a license to display the preprint in perpetuity.

It is made available under a CC-BY-NC-ND 4.0 International license.

\title{
CLINICAL EVALUATION OF IFN BETA1B IN COVID-19 PNEUMONIA: A
}

\section{RETROSPECTIVE STUDY}

Miriam Estébanez, M.D*, German Ramírez-Olivencia, M.D, Tatiana Mata, Ph.D, David Martí, M.D, Carlos Gutierrez, Ph.D, Begoña de Dios, Ph.D, María Dolores Herrero, Ph.D, Ana Roel, PhD, Yolanda Martínez, Nurse, Alejandro Aguirre, Ph.D, Francisco, Alcántara-Nicolás, M.D, Pablo Fernández- González, MD, Elena López, Ph.D, Lucía, Elena Ballester, M.D, María Mateo-Maestre, M.D, Sergio Campos, M.D, María Jesús Sánchez-Carrillo, Ph.D, Antonio Fe, M.D., Francisco Javier Membrillo de Novales, M.D, COVID 19 CENTRAL DEFENSE HOSPITAL “GÓMEZ ULLA” TEAM

Central Defense Hospital "Gómez Ulla"

Glorieta Ejército, 1, 28047 Madrid (Spain)

Telephone: 914222000

* Corresponding author:

Dra. Miriam Estébanez Muñoz, MD, PhD

CRBN \& Infectious Diseases Unit. HLIU

Internal Medicine Department

Central Defense Hospital "Gómez Ulla", Madrid, Spain.

e-Mail: mestmun@mde.es 
medRxiv preprint doi: https://doi.org/10.1101/2020.05.15.20084293; this version posted May 21,2020 . The copyright holder for this preprint

\section{RESEARCH IN CONTEXT}

Evidence before this study: We searched Pubmed on April $27^{\text {th }}, 2020$, for articles evaluating the efficacy of interferon beta in patients infected with severe acute respiratory syndrome coronavirus 2 (SARS-CoV-2), using the terms: "interferon beta and (COVID19 or SARS-CoV-2)". We only found 5 articles. Of them, there was only one original article in English, which was a descriptive study of a case series with solid organ transplant from Spain.

Added value of this study: This is the first article that reports the efficacy of interferon betalb in the treatment of patients with COVID-19. We compared the in-hospital mortality between patients who received interferon betalb and patients who did not. Patients in both groups received other drugs with a potential antiviral and immunomodulatory effect. There was no significant difference in in-hospital mortality between both groups.

Implications of all the available evidence: In our retrospective cohort, treatment with interferon betalb had not impact on in-hospital survival, however it would be of clinical interest to evaluate the effect of early administration of this drug in the control of SARSCoV-2 infection in larger randomized clinical trials. 
medRxiv preprint doi: https://doi.org/10.1101/2020.05.15.20084293; this version posted May 21 , 2020. The copyright holder for this preprint (which was not certified by peer review) is the author/funder, who has granted medRxiv a license to display the preprint in perpetuity.

\section{ABSTRACT \\ Background}

COVID-19 pneumonia is associated with significant mortality and has no approved antiviral therapy. Interferon beta1 has shown in vitro studies a potent inhibition of SARS$\mathrm{CoV}$ and MERS-CoV. In an in vitro study, SARS-CoV-2 had more sensitivity to IFN-I pretreatment that SARS-CoV. A combination of IFN beta $1 \mathrm{~b}$ administered subcutaneously with other antiviral treatments has been recommended in several guidelines. However, clinical trial results for the treatment of COVID-19 are pending. We aimed to assess the efficiency of IFN betalb in COVID19 comparing the in-hospital mortality between patients who received IFN betalb and patients did not receive.

\section{Methods}

In this retrospective cohort study, we included hospitalized adults with COVID-19 between February 23th and April 4th, 2020, at the Central Defense Hospital (Madrid, Spain). Subcutaneous interferon beta-1b was recommended in moderate-severe pneumonia. The primary endpoint was in-hospital mortality. Univariate and multivariate analysis was performed to identify variables associated with in-hospital mortality.

\section{Findings}

We analyzed 256 patients (106 patients in interferon group and 150 patients in control group). At admission, patients who did not receive interferon betalb presented a greater number of comorbidities. The overall mortality rate was $24.6 \%(63 / 256)$. Twenty-two patients $(20.8 \%)$ in the interferon group died and $41(27.3 \%)$ in the control group $(p=0.229)$. In the multivariate analysis, the predictors of in-hospital mortality were age, severity of clinical picture at admission and hydroxychloroquine treatment. 
medRxiv preprint doi: https://doi.org/10.1101/2020.05.15.20084293; this version posted May 21, 2020. The copyright holder for this preprint (which was not certified by peer review) is the author/funder, who has granted medRxiv a license to display the preprint in perpetuity.

It is made available under a CC-BY-NC-ND 4.0 International license.

\section{Interpretation}

In hospitalized patients with COVID-19, interferon beta1b treatment was not associated to decrease in-hospital mortality. Further assessment of the earlier administration of this drug in randomized trials is recommended.

Funding: none. 
medRxiv preprint doi: https://doi.org/10.1101/2020.05.15.20084293; this version posted May 21 , 2020. The copyright holder for this preprint (which was not certified by peer review) is the author/funder, who has granted medRxiv a license to display the preprint in perpetuity.

\section{INTRODUCTION}

A new respiratory disease was reported to the WHO China Country Office on 31

December 2019 (1). A cluster of cases of pneumonia of unknown etiology had been detected in Wuhan City, Hubei Province of China, causing severe respiratory illness similar to severe acute respiratory syndrome coronavirus and was associated with ICU admission and high mortality in some cases (2). A new type of coronavirus (named lately SARS-CoV-2), was isolated on 7 January 2020 (3). On January 30th, 2020, WHO declared the outbreak of nCoV-2019 as a Public Health Emergency of International Concern (PHEIC) (4). From the initial description, the disease has spread around the world becoming a pandemic threat, and has affected not only health, but economic and social affairs. By April 27th, 2020, there were more than 2.5M total confirmed cases and more than 180000 deaths, in 213 countries (5).

Initial descriptions reported flu-like symptoms such as fever, cough, dysnea, headache, myalgias and asthenia. Digestive complains were also reported including nausea, vomiting and diarrhea. With spreading of the disease, there here have been described new clinical features of the disease, such as neurological, myocardial, ophtalmic, cutaneous or thrombotic events. When coronavirus invades the host, a complex intracellular mechanism is activated, and synthesis of type I interferons (IFNs) is promoted. SARSCoV-2 penetrates alveolar cell (pneumocytes type II) using the receptor for angiotensinconverting enzyme 2 (ACE-2), a membrane exopeptidase. Activating the downstream JAK STAT signal-pathway, IFNs limit virus spread, and play an immunomodulatory role through macrophage, NK cells and T/B cells. Blocking the production of IFNs allows virus to survive (6). On the other hand, coronavirus infection activates the immune system generating an excessive response that could lead to greater lung injury and worse clinical evolution. However, this hyperactivation is insufficient to control the infection and leads 
medRxiv preprint doi: https://doi.org/10.1101/2020.05.15.20084293; this version posted May 21 , 2020. The copyright holder for this preprint (which was not certified by peer review) is the author/funder, who has granted medRxiv a license to display the preprint in perpetuity.

It is made available under a CC-BY-NC-ND 4.0 International license .

to further tissue damage, being able to develop the Adult Respiratory Distress Syndrome (ARDS); the latter has been described as the main cause of mortality from COVID-19. Excessive activation of the innate immune system also causes damage to the microvascular system and activates the coagulation system and inhibition of fibrinolysis, causing sepsis-induced coagulopathy or disseminated intravascular coagulation, with widespread microcirculatory disorders leading to the development of multi-organ failure. Recommendations about treatment, initially based on antiviral drugs, are now considering immunomodulation as a key stone but not the only one. Several different treatments have been used for COVID-19, including lopinavir/ritonavir, interferon, hydroxicloroquine, tocilizumab, baricitinib, immunoglobulin and corticoids with no or conflicting results. No approved treatment is currently available, but there are therapeutic strategies in SARS and MERS-CoV disease on clinical or preclinical research that would suggest interferon as pillar tool in COVID-19.

Antiviral effect of interferon has been described in other positive single-stranded RNA virus diseases such as $\mathrm{HCV}$. Antiviral activity is based on the activation of RNase that breaks-down the nucleic acid chain of the virus. In addition, it blocks the translation of RNA, prevents encapsidation and viral release (7). There are in vitro tests showing activity against MERS-CoV (8) and studies on animal models had promising results (9), but studies to evaluate clinical efficacy had variable outcomes (lo 111213 ).

The aim of this study is to assess the effectivity and safety of interferon betalb in the treatment of COVID-19 pneumonia. 
medRxiv preprint doi: https://doi.org/10.1101/2020.05.15.20084293; this version posted May 21 , 2020. The copyright holder for this preprint (which was not certified by peer review) is the author/funder, who has granted medRxiv a license to display the preprint in perpetuity.

\section{METHODS}

\section{Study design and participants}

This is a single-center retrospective cohort study. We enrolled all hospitalized adults (aged $\geq 16$ years) at the Central Defense Hospital "Gómez Ulla" (Madrid, Spain) with COVID-19 and had a definitive outcome (dead or discharge) between February 23th and April 4th. COVID-19 diagnosis was defined according to Spanish Ministry of Health definitions on March 19th, 2020. COVID19 case including confirmed cases by reversetranscriptase-polymerase chain-reaction (RT-PCR) assay for SARS-CoV-2 in a respiratory tract sample and probable cases (bilateral interstitial pneumonia with clinical picture compatible with a COVID-19 diagnosis with no laboratory tests or nonconcluding SARS-CoV-2 test). No exclusion criteria were applied at this stage.

\section{Data collection}

Demographical data, comorbidities, treatments prescribed for COVID-19, clinical severity at admission and analytical parameters at admission were extracted from the electronic medical records by two physicians and entered into a database. In case of differences of interpretation a third investigator checked the medical records and adjudicated any difference.

\section{Definitions}

Severity of clinical picture at admission was defined according to Ministry of Health of Spain medical treatment protocol, March 19th, 2020: mild (SpO2 in rest above 93\%), moderate (need for supplemental oxygen with fraction of inspired oxygen less than $50 \%$ ), severe (who required mechanical ventilation or had a fraction of inspired oxygen of at least $50 \%$ or more). 
medRxiv preprint doi: https://doi.org/10.1101/2020.05.15.20084293; this version posted May 21 , 2020. The copyright holder for this preprint (which was not certified by peer review) is the author/funder, who has granted medRxiv a license to display the preprint in perpetuity.

It is made available under a CC-BY-NC-ND 4.0 International license .

Hypertension was defined as previous arterial hypertension requiring any pharmacological treatment. Diabetes Mellitus was defined as previous hyperglycemia requiring any pharmacological hypoglycemic treatment. Dyslipidemia was defined as previous alteration in lipid profile requiring pharmacological treatment. Cardiomyopathy was defined as any previous diagnosis of cardiac chronic disease or acute cardiac event. Respiratory disease was defined as any previous lower respiratory tract chronic disease requiring chronic pharmacological treatment. Cancer was defined as any previously diagnosed malignancy. Dementia was defined as any mental chronic disease altering cognitive capabilities.

\section{Procedures}

Interferon beta1b (Betaferon $\left.{ }^{\circledR}\right)$ was given by subcutaneous injection at a dose of $250 \mu \mathrm{g}$ on alternate days. Patients included in the interferon group had received at least one dose. Local treatment protocol recommended interferon betalb in the hospitalized patients with moderate-severe pneumonia, with a duration between 3-5 doses. The number of doses was at the discretion of the clinician according to the evolution of the patient and tolerance. Patients in both groups were treated with other specific drugs with potential activity against SARS-CoV-2 and/or COVID-19 immune disorders leading to ARDS. These drugs could include antivirals (lopinavir/ritonavir, and/or hydroxychloroquine or chloroquine), and/or anti-inflammatory drugs (steroids and/or tocilizumab). Antibiotics were scheduled only in the case of suspected bacterial infection.

In addition to regular clinical monitoring, renal function, liver enzymes, and blood count were assessed at baseline and closely throughout the treatment course at the discretion of the clinician. Chest radiographs were also done for all inpatients. 
medRxiv preprint doi: https://doi.org/10.1101/2020.05.15.20084293; this version posted May 21 , 2020. The copyright holder for this preprint (which was not certified by peer review) is the author/funder, who has granted medRxiv a license to display the preprint in perpetuity.

It is made available under a CC-BY-NC-ND 4.0 International license.

\section{Outcomes}

The primary endpoint was in-hospital mortality in two different regimens: with and without interferon beta1b.

\section{Statistical methods}

Simple characteristics were described using absolute and relative frequencies for categorical variables and means $\pm \mathrm{SD}$ or median (IQR) for continuous variables. Chisquare test or the nonparametric Mann-Whitney U-test were used to compare continuous baseline variables. Comparisons of categorical variables between groups were conducted using the Pearson's chi-squared test or Fisher's exact test, as appropriate.

Univariate analysis was performed to identify variables associated with mortality. The variables evaluated were: age, sex, presence of comorbidities (hypertension, dyslipidemia, diabetes, lung disease, heart disease, cancer, dementia), number of comorbidities, clinical severity at admission (mild, moderate, severe), laboratory parameters at admission and use of other treatments. Age and laboratory parameters were categorized in according to the ROC curves of each parameter: age ( $<65$ vs. $\geq 65$ years), lymphocytes ( $<1000 \mathrm{cls} . / \mathrm{uL}$ vs. $\geq 1000 \mathrm{cls} . / \mathrm{uL})$, C-reactive protein $(<14 \mathrm{mg} / \mathrm{dl} \mathrm{vs} . \geq 14$ mg/dl), D-dimer $(<1000 \mathrm{ng} / \mathrm{mL}$ vs. $\geq 1000 \mathrm{ng} / \mathrm{mL})$, ferritin $(<1000 \mathrm{ng} . / \mathrm{mL}$ vs. $\geq 1000$ ng./mL), lactate dehydrogenase $(<400 \mathrm{U} / \mathrm{L}$ vs. $\geq 400 \mathrm{U} / \mathrm{L})$. A multivariate logistic regression of variables with significance in univariate analysis of $\mathrm{p}<0,1$ was performed. Statistical analysis was performed using SPSS version 25 statistical package. All tests were 2-sided, $\mathrm{p}$ values $<0.05$ were considered significant. 
medRxiv preprint doi: https://doi.org/10.1101/2020.05.15.20084293; this version posted May 21 , 2020. The copyright holder for this preprint (which was not certified by peer review) is the author/funder, who has granted medRxiv a license to display the preprint in perpetuity.

\section{Ethics approvals}

From beginning of COVID-19 epidemic, eligible hospitalized patients were offered treatment with subcutaneous interferon betalb after informed verbal consent was obtained from the patients themselves or their closest relative. The research protocol was approved by the Ethics Committee on Clinical Investigation of the Ministry of Defense of Spain (code 25/20).

\section{Role of funding source}

No external funding was received for this study.

\section{RESULTS}

A total of 256 patients with COVID19 were admitted in our hospital, and died or have been discharged between February 23th and April 4th. Most patients were male (59.4\%) with mean age of 63.7 years. The most frequent comorbidity was hypertension (44.5\%), followed by dyslipemia and cardiopathy (Table 1). Overall patients included, $61.2 \%$ presented at least two comorbidities. Median time from illness onset to hospital admission was 7 days (IQR 3-9). At admission, $46.3 \%$ of patients had a mild clinical picture, $36.1 \%$ moderate and $17.6 \%$ severe. At hospital discharge, $89.5 \%$ of patients has been diagnosed with pneumonia. Most of the patients in our cohort received hydroxychloroquine (77\%), followed by azythromycin (62.9\%), interferon beta1b (41.4\%), lopinavir/ritonavir (36.1\%), and corticosteroids (25.8\%).

Of all the patients of our cohort, 106 were treated with interferon betalb. No significant differences were observed upon comparing the two groups in demographics variables, comorbidities, severity clinical at admission and level of biomarkers at admission. There was more percentage of patients with at least 2 comorbidities in the group not receiving interferon $(46.3 \%$ vs. $34.9 \%, \mathrm{p}=0.069)$ (Table 1$)$. 
medRxiv preprint doi: https://doi.org/10.1101/2020.05.15.20084293; this version posted May 21 , 2020. The copyright holder for this preprint (which was not certified by peer review) is the author/funder, who has granted medRxiv a license to display the preprint in perpetuity.

It is made available under a CC-BY-NC-ND 4.0 International license .

In the interferon group, more patients received hydroxychloroquine $(95.3 \%$ vs. $64 \%$, $\mathrm{p}<0.001)$ and lopinavir/ritonavir $(44.3 \%$ vs. $30.2 \%, \mathrm{p}=0.021)$. There was no difference in in-hospital mortality between the group receiving the combination of interferon betalb and lopinavir/ritonavir versus the group of patients receiving interferon betalb without lopinavir/ritonavir $(\mathrm{p}=0.906)$

\section{Outcome}

The overall mortality rate was $24.6 \%$ (63/256). Twenty-two patients $(20.8 \%)$ receiving interferon betalb died and $41(27.3 \%)$ patients not receiving interferon bealb $(\mathrm{p}=0.229)$.

\section{Mortality risk factors}

In the multivariate analysis age (older than 65 years old), clinical severity at admission, and not have received hydroxychloroquine were significantly associated with in-hospital mortality (Table 2). The interferon treatment was not associated with survival benefit neither univariate analysis nor multivariate analysis.

\section{DISCUSSION}

Three human coronavirus (SARS-CoV, MERS-CoV and SARS-CoV-2) cause severe pneumonia. Rapid virus replication reaching high titers and associated enhanced inflammatory responses, are believed to contribute to pathogenicity (14 15 16). Type 1 IFNs generally protect mammalian hosts from virus infections, but in some cases, IFN-I is pathogenic. In MERS-CoV-infected mice, IFN-I administration within 1 day after infection protected mice from lethal infection. In contrast, delayed IFN- $\beta$ treatment failed to inhibit virus replication and enhanced proinflammatory cytokine expression, resulting in fatal pneumonia (17). In that way, it seems that the timing of IFN-I administration is a crucial factor in the effectiveness of the treatment. In an in vitro study, the IFN-I pretreatment resulted in a significant reduction in viral replication in Vero E6 cells infected with SARS-CoV-2 in compared to control untreated cells (18). 
medRxiv preprint doi: https://doi.org/10.1101/2020.05.15.20084293; this version posted May 21 , 2020. The copyright holder for this preprint (which was not certified by peer review) is the author/funder, who has granted medRxiv a license to display the preprint in perpetuity.

It is made available under a CC-BY-NC-ND 4.0 International license .

In our cohort, the median time from the start of symptoms to hospital admission was 7 days in both groups. We do not know if earlier administration would have changed the results of our study. In recently published clinical trial in severe COVID-19, lopinavir/ritonavir treatment within 12 days after the onset of symptoms was associated with shorter time to clinical improvement but later it was not (19).

In our cohort, in-hospital mortality in patients not receiving interferon betalb was higher than in the interferon group, although the difference was not significant. Most patients in both treatment groups were receiving other potentially effective drugs, as hydroxychloroquine or azytromycin, making it difficult to demonstrate efficacy of a treatment individually in a retrospective analysis. Results from in vitro and animal studies suggest that a combination of lopinavir/ritonavir and interferon- $\beta 1 \mathrm{~b}$ may be effective against MERS-CoV. A randomized controlled trial is ongoing to evaluate this combination as a potential treatment for MERS (MIRACLE trial) (20). To explore the efficacy of this combination in SARS-CoV-2, we compare in-hospital mortality between patients receiving interferon betalb with and without lopinavir/ritonavir and no difference in in-hospital mortality was found.

There were no significant differences in baseline characteristics between two groups, including the clinical severity of pneumonia on admission. On admission, almost half of the patients presented mild pneumonia in both groups (interferon and control). In fact, $45 \%$ of patients who received interferon betalb during hospitalization presented mild pneumonia on admission. Although treatment with interferon was indicated in moderatesevere pneumonia, there was a shortage of the drug, so not all patients could receive treatment despite being indicated. In this context, interferon betalb treatment was prioritized based on life expectancy prior to admission. This explains why there were 
medRxiv preprint doi: https://doi.org/10.1101/2020.05.15.20084293; this version posted May 21 , 2020. The copyright holder for this preprint (which was not certified by peer review) is the author/funder, who has granted medRxiv a license to display the preprint in perpetuity.

It is made available under a CC-BY-NC-ND 4.0 International license .

more patients with dementia and other comorbidities in patients not receiving interferon beta1b.

In the multivariate analysis, the predictors of in-hospital mortality were age, severity of pneumonia on admission, and treatment with hydroxychloroquine. The survival benefit found with hydroxychloroquine treatment supports the findings of a previous study of our research group in this sense (under per review). In addition, severity clinical on admission as predictor of mortality is a finding reported in MERS. So, Mohammed Al Ghamdi et al. found in a retrospective cohort study that patients receiving beta interferon and mofetil had improved survival, however this was confounded by the severity of illness on presentation for beta interferon (21).

Our study has the limitations of a retrospective study, selection and unmeasured confounding bias cannot be completely excluded. It would have been ideal to have had microbiological confirmation of all the patients, but since this study had been carried out in the worst phase of the epidemic in our country, at specific times and due to lack of tests, microbiological confirmation was not necessary in cases of high clinical and radiological suspicion without any other alternative cause. Furthermore, we cannot evaluate differences between the two groups in terms of virus elimination, as there was no RT-PCR monitoring for all patients.

This study is, to the best our knowledge, the first clinical study that evaluates the effectiveness of the interferon betalb in SARS-CoV-2 infection.

\section{Conclusion}

In our retrospective cohort, the interferon betalb treatment had no significant impact on in-hospital survival. We consider that it would be of interest to explore the efficacy of the early administration of this drug in controlled clinical trials, with a larger sample size. 
medRxiv preprint doi: https://doi.org/10.1101/2020.05.15.20084293; this version posted May $21,2020$. The copyright holder for this preprint (which was not certified by peer review) is the author/funder, who has granted medRxiv a license to display the preprint in perpetuity.

It is made available under a CC-BY-NC-ND 4.0 International license .

Table 1. General characteristics of the patients in both treatment groups (with and without INF1ß1b).

\begin{tabular}{|c|c|c|c|c|c|}
\hline & \multirow{2}{*}{$\begin{array}{c}\text { GLOBAL } \\
\qquad \begin{array}{l}\text { N=256 }\end{array}\end{array}$} & & \multicolumn{2}{|c|}{ INF $\beta 1 b$} & \multirow[b]{2}{*}{$\boldsymbol{P}$} \\
\hline & & & $\begin{array}{c}\text { Yes } \\
n=106\end{array}$ & $\begin{array}{c}\text { No } \\
n=150\end{array}$ & \\
\hline Age (years) $\bar{x}(D E)$ & $63.7(17)$ & & $\begin{array}{c}61.9 \\
(16.62)\end{array}$ & $\begin{array}{l}64.83 \\
(17.16)\end{array}$ & 0.793 \\
\hline Male n (\%) & $\begin{array}{c}152 \\
(59.4 \%)\end{array}$ & & $67(63.2 \%)$ & $85(56.7 \%)$ & 0.294 \\
\hline HTA n $(\%)$ & $\begin{array}{c}114 \\
(44.5 \%)\end{array}$ & & $41(38.7 \%)$ & $73(48.7 \%)$ & 0.113 \\
\hline $\operatorname{DMn}(\%)$ & $47(18.4 \%)$ & & $16(15.1 \%)$ & $31(20.7 \%)$ & 0.257 \\
\hline Dyslipidaemia n (\%) & $78(30.6 \%)$ & & $31(29.2 \%)$ & $47(31.5 \%)$ & 0.695 \\
\hline Cardiopathy n (\%) & $57(22.4 \%)$ & & $20(18.9 \%)$ & $37(24.8 \%)$ & 0.260 \\
\hline Cancer n (\%) & $29(11.4 \%)$ & & $11(10.4 \%)$ & $18(12.1 \%)$ & 0.673 \\
\hline Dementia n (\%) & $21(8.2 \%)$ & & $5(4.7 \%)$ & $16(10.7 \%)$ & 0.085 \\
\hline Pulmonary disease $\mathrm{n}(\%)$ & $37(14.5 \%)$ & & $12(11.3 \%)$ & $25(16.8 \%)$ & 0.223 \\
\hline Comorbidities (at least one) n (\%) & $\begin{array}{c}156 \\
(61.2 \%)\end{array}$ & & $61(57.5 \%)$ & $95(63.8 \%)$ & 0.316 \\
\hline Comorbidities (at least two) n (\%) & $\begin{array}{c}106 \\
(61.2 \%)\end{array}$ & & $37(34.9 \%)$ & $69(46.3 \%)$ & 0.069 \\
\hline \multirow{3}{*}{ Clinical severity at admission $\mathrm{n}(\%)$} & $\begin{array}{c}118 \\
(46.3 \%)\end{array}$ & Mild & $48(45.3 \%)$ & $70(47.0 \%)$ & \multirow{3}{*}{0.895} \\
\hline & $92(36.1 \%)$ & Moderate & $40(37.7 \%)$ & $52(34.9 \%)$ & \\
\hline & $45(17.6 \%)$ & Severe & $18(17.0 \%)$ & $27(18.1 \%)$ & \\
\hline $\begin{array}{l}\text { Days from the onset of the } \\
\text { symptoms to hospital admission } \\
\text { Md (IQR) }\end{array}$ & $7(3-9)$ & & $7(3-8)$ & $7(3-10)$ & 0.653 \\
\hline D-dimer ng/ml Md (IQR) & 701 & & 668 & 724 & 0.937 \\
\hline
\end{tabular}


medRxiv preprint doi: https://doi.org/10.1101/2020.05.15.20084293; this version posted May 21,2020 . The copyright holder for this preprint (which was not certified by peer review) is the author/funder, who has granted medRxiv a license to display the preprint in perpetuity.

It is made available under a CC-BY-NC-ND 4.0 International license.

\begin{tabular}{|c|c|c|c|c|}
\hline & $(438-1169)$ & $(488-1200)$ & $(380-1159)$ & \\
\hline Ferritin ng/ml Md (IQR) & $\begin{array}{c}425 \\
(311-1544)\end{array}$ & $\begin{array}{c}664 \\
(242-1160)\end{array}$ & $\begin{array}{c}425 \\
(311-1785)\end{array}$ & 0.807 \\
\hline Leukocytes cel/ $\mu \mathrm{L} \bar{x}(D E)$ & $\begin{array}{l}7,259 \\
(3280)\end{array}$ & $\begin{array}{r}7,375 \\
(3390)\end{array}$ & $\begin{array}{c}7,178 \\
(3210)\end{array}$ & 0.507 \\
\hline Lymphocytes cel $/ \mu \mathrm{L} \bar{x}(D E)$ & $\begin{array}{l}1,132 \\
(546)\end{array}$ & $\begin{array}{l}1,168 \\
(566)\end{array}$ & $1,106(531)$ & 0.720 \\
\hline $\mathrm{LDH} \mathrm{U} / 1 \bar{x}(D E)$ & $349(131)$ & $345(113)$ & $352(143)$ & 0.673 \\
\hline PCR mg/dl Md (IQR) & $\begin{array}{c}8.8 \\
(3.7-15.8)\end{array}$ & $\begin{array}{c}8.4 \\
(4-16)\end{array}$ & $\begin{array}{c}9.3 \\
(3.6-15.6)\end{array}$ & 0.973 \\
\hline Hydroxychloroquine $\mathrm{n}(\%)$ & $197(77 \%)$ & $\begin{array}{c}101 \\
(95.3 \%)\end{array}$ & $96(64.0 \%)$ & $<0.001$ \\
\hline Lopinavir/ritonavir $\mathrm{n}(\%)$ & $92(36.1 \%)$ & $47(44.3 \%)$ & $45(30.2 \%)$ & 0.021 \\
\hline Azythromycin n (\%) & $\begin{array}{c}158 \\
(62.9 \%)\end{array}$ & $64(61.0 \%)$ & $94(64.4 \%)$ & 0.579 \\
\hline Corticosteroids n $(\%)$ & $66(25.8 \%)$ & $24(22.6 \%)$ & $42(28.8 \%)$ & 0.334 \\
\hline Tocilizumab n (\%) & $5(2 \%)$ & $3(2,8 \%)$ & $2(3 \%)$ & 0,652 \\
\hline
\end{tabular}


medRxiv preprint doi: https://doi.org/10.1101/2020.05.15.20084293; this version posted May 21, 2020. The copyright holder for this preprint (which was not certified by peer review) is the author/funder, who has granted medRxiv a license to display the preprint in perpetuity.

It is made available under a CC-BY-NC-ND 4.0 International license .

Table 2. Multivariate analysis. Risks factors for hospital mortality in COVID-19 pneumonia

\begin{tabular}{|l|c|c|c|}
\hline & OR & $\mathbf{9 5 \% C I}$ & P value \\
\hline Age $(<65$ years $)$ & 0.002 & $0.00-0.27$ & 0.002 \\
\hline Hidroxychloroquine & 0.158 & $0.03-0.79$ & 0.025 \\
treatment & 0.032 & $0.00-0.18$ & $<0.001$ \\
Clinical severity * & 0.089 & $0.01-0.44$ & 0.003 \\
\hline \multicolumn{1}{|c|}{ Mild } & & & \\
\hline
\end{tabular}

* Compared to severe

OR: Odd Ratio; CI: Confidence interval. 
medRxiv preprint doi: https://doi.org/10.1101/2020.05.15.20084293; this version posted May 21 , 2020. The copyright holder for this preprint (which was not certified by peer review) is the author/funder, who has granted medRxiv a license to display the preprint in perpetuity.

It is made available under a CC-BY-NC-ND 4.0 International license .

\section{REFERENCES}

1. WHO | Pneumonia of unknown cause - China. WHO. 2020.

2. Huang C, Wang Y, Li X, Ren L, Zhao J, Hu Y, et al. Clinical features of patients infected with 2019 novel coronavirus in Wuhan, China. Lancet (London, England) [Internet]. 2020 Jan 24 [cited 2020 Feb 5]; Available from: http://www.ncbi.nlm.nih.gov/pubmed/31986264

3. WHO | Novel Coronavirus - China [Internet]. [cited 2020 Feb 5]. Available from:

https://www.who.int/csr/don/12-january-2020-novel-coronavirus-china/en/

4. Statement on the second meeting of the International Health Regulations (2005) Emergency Committee regarding the outbreak of novel coronavirus (2019nCoV) [Internet]. [cited 2020 Feb 5]. Available from: https://www.who.int/newsroom/detail/30-01-2020-statement-on-thesecondmeeting-of-the-international-health-regulations-(2005)-emergencycommitteeregarding-the-outbreak-of-novel-coronavirus-(2019-ncov)

5. Coronavirus disease 2019 [Internet]. [cited 2020 Apr 27]. Available from: https://www.who.int/emergencies/diseases/novel-coronavirus-2019

6. Li G, Fan Y, Lai Y, Han T, Li Z, Zhou P, et al. Coronavirus infections and immune responses. J Med Virol 2020; 92:424-32.

7. Lin F ching, Young HA. Interferons: Success in anti-viral immunotherapy. Vol. 25, Cytokine and Growth Factor Reviews. Elsevier Ltd; 2014. p. 369-76.

8. Chan JFW, Chan KH, Kao RYT, To KKW, Zheng BJ, Li CPY, et al. Broadspectrum antivirals for the emerging Middle East respiratory syndrome coronavirus. J Infect 2013;67:606-16. 
medRxiv preprint doi: https://doi.org/10.1101/2020.05.15.20084293; this version posted May 21 , 2020. The copyright holder for this preprint (which was not certified by peer review) is the author/funder, who has granted medRxiv a license to display the preprint in perpetuity.

It is made available under a CC-BY-NC-ND 4.0 International license .

9. Fuk-Woo Chan J, Yao Y, Yeung M-L, Deng W, Bao L, Jia L, et al. Treatment With Lopinavir/Ritonavir or Interferon- $\beta 1 \mathrm{~b}$ Improves Outcome of MERS-CoV Infection in a Nonhuman Primate Model of Common Marmoset. 2015 [cited 2020 Apr 27]; Available from:https://academic.oup.com/jid/articleabstract/212/12/1904/2911949

10. Spanakis N, Tsiodras S, Haagmans BL, Raj VS, Pontikis K, Koutsoukou A, et al. Virological and serological analysis of a recent Middle East respiratory syndrome coronavirus infection case on a triple combination antiviral regimen. Int J Antimicrob Agents 2014;44:528-32.

11. Omrani AS, Saad MM, Baig K, Bahloul A, Abdul-Matin M, Alaidaroos AY, et al. Ribavirin and interferon alfa-2a for severe Middle East respiratory syndrome coronavirus infection: a retrospective cohort study. Lancet Infect Dis $2014 ; 14: 1090-5$.

12. Al-Tawfiq JA, Momattin H, Dib J, Memish ZA. Ribavirin and interferon therapy in patients infected with the Middle East respiratory syndrome coronavirus: An observational study. Int J Infect Dis 2014;20:42-6.

13. Shalhoub, S. et al. IFN- $\alpha 2$ a or IFN- $\beta 1 \mathrm{a}$ in combination with ribavirin to treat Middle East respiratory syndrome coronavirus pneumonia: a retrospective study. J Antimicrob Chemother 2015;70: 2129-32.

14. Baseler LJ, Falzarano D, Scott DP, Rosenke R, Thomas T et al. An Acute Immune Response to Middle East Respiratory Syndrome Coronavirus Replication Contributes to Viral Pathogenicity. Am J Pathol. 2016;186:630-8.

15. van den Brand JM, Haagmans BL, van Riel D, Osterhaus AD, Kuiken T. The pathology and pathogenesis of experimental severe acute respiratory syndrome and influenza in animal models. J Comp Pathol. 2014;151:83-112. 
medRxiv preprint doi: https://doi.org/10.1101/2020.05.15.20084293; this version posted May 21 , 2020. The copyright holder for this preprint (which was not certified by peer review) is the author/funder, who has granted medRxiv a license to display the preprint in perpetuity.

It is made available under a CC-BY-NC-ND 4.0 International license .

16. Channappanavar R, Fehr AR, Vijay R, Mack M, Zhao J, Meyerholz DK, Perlman S. Dysregulated Type I Interferon and Inflammatory MonocyteMacrophage Responses Cause Lethal Pneumonia in SARS-CoV-Infected Mice. Cell Host Microbe. 2016;19:181-93.

17. Channappanavar R, Fehr AR, Zheng J, Wohlford-Lenane C, Abrahante JE, Mack M, Sompallae R, McCray PB Jr, Meyerholz DK, Perlman S. IFNI response timing relative to virus replication determines MERS coronavirus i nfection outcomes. J Clin Invest 2019;130:3625-3639.

18. BioRxiv preprint doi: https://doi.org/10.1101/2020.03.07.982264.

19. Cao B1, Wang Y1, Wen D1, Liu W1, Wang J1, Fan G1, et al. A Trial of Lopinavir-Ritonavir in Adults Hospitalized with Severe Covid-19. N Engl J Med. 2020 Mar 18. [Epub ahead of print]

20. 20 Arabi YM, Alothman A, Balkhy HH, Al-Dawood A, AlJohani S, Al Harbi S, Kojan S et al. Treatment of Middle East Respiratory Syndrome with a combination of lopinavir-ritonavir and interferon- $\beta 1 \mathrm{~b}$ (MIRACLE trial): study protocol for a randomized controlled trial. Trials. 2018;19:81.

21. Al Ghamdi M, Alghamdi KM, Ghandoora Y, Alzahrani A, Salah F, Alsulami
A, Bawayan
MF, Vaidya
D, Perl
TM, Sood
G.

Treatment outcomes for patients with Middle Eastern Respiratory Syndrome Coronavirus (MERSCoV) infection at a coronavirus referral center in the Kingdom of Saudi Arabia. BMC Infect Dis. 2016;16:174. 